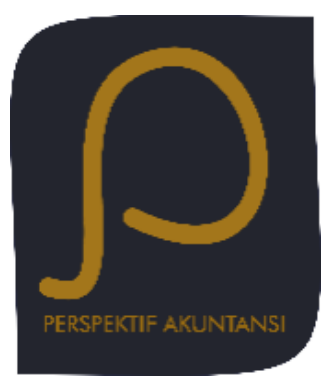

Perspektif Akuntansi

Volume 3 Nomor 3 (Oktober 2020), hal. 197-215

ISSN: 2623-0194 (Print), 2623-0186 (Online)

Copyright(C The Authors(s). All Rights Reserved

Center for Accounting Development and Research (CARD)

Program Studi Akuntansi

Fakultas Ekonomika dan Bisnis,

Universitas Kristen Satya Wacana

DOI: https://doi.org/10.24246/persi.vXiX.p197-215

http://ejournal.uksw.edu/persi

\title{
Analisis Kinerja Keuangan Pada Perusahaan Daerah Air Minum (PDAM) Kota Makassar
}

\author{
Randi Tangdialla ${ }^{1}$ \\ Universitas Kristen Indonesia Toraja \\ Luther P. Tangdialla \\ Universitas Kristen Indonesia Paulus \\ Dwita Natalia \\ Universitas Kristen Indonesia Paulus \\ Ade Lisa Matasik \\ Universitas Kristen Indonesia Toraja
}

Received

12/10/2020

Revised

09/02/2021

Accepted

16/02/2021
Abstract. This study aims to measure and analyze the financial performance of the Municipal Waterworks of Makassar City based on regulation Minister of Home Affairs Indonesia Number 47 of 1999. The data of this study uses secondary data, namely the financial statements from the Municipal Waterworks of the Makassar City in 2015-2017. The method used in this research is quantitative descriptive method. The results show that the measurement of the financial performance of the Municipal Waterworks of Makassar City based on 10 indicators set by the regulation Minister of Home Affairs Indonesia Number 47 of 1999 in 2015 has a financial aspect performance value of 66.67 in the category of "Good", in 2016 it has a performance value of 83 financial aspects 31 in the "Very Good" category and in 2017 it had a performance value of 81.67 in the financial aspect in the "Very Good" category. Therefore, it can show the average value of the performance of the financial aspects of PDAM Makassar City shows a "Very Good" performance with an average value of 77.22. 
Keywords: Financial Performance, Municipal Waterworks Performance Appraisal Guidelines, Municipal Waterworks

\begin{abstract}
Abstrak. Penelitian ini bertujuan untuk mengukur dan menganalisis kinerja keuangan Perusahaan Daerah Air Minum (PDAM) Kota Makassar berdasarkan Kepmendagri Nomor 47 Tahun 1999. Data penelitian ini menggunakan data sekunder yaitu laporan keuangan PDAM Kota Makassar periode 2015-2017. Metode yang digunakan dalam penelitian ini adalah metode deskriptif kuantitatif. Hasil penelitian ini menunjukkan bahwa pengukuran kinerja keuangan PDAM Kota Makassar berdasarkan 10 indikator yang telah ditetapkan oleh Kepmendagri Nomor 47 Tahun 1999 pada tahun 2015 memiliki nilai kinerja aspek keuangan sebesar 66,67 dengan kategori "Baik", pada tahun 2016 memiliki nilai kinerja aspek keuangan 83,31 dengan kategori "Baik Sekali" dan pada tahun 2017 memiliki nilai kinerja aspek keuangan 81,67 dengan kategori "Baik Sekali". Sehingga secara umum dapat disimpulkan rata-rata kinerja aspek keuangan PDAM Kota Makassar menunjukkan kinerja "Baik Sekali" dengan nilai rata-rata 77,22.
\end{abstract}

Kata kunci: Kinerja Keuangan, Pedoman Penilaian Kinerja PDAM, Perusahaan Daerah Air Minum (PDAM)

\title{
Pendahuluan
}

Untuk menjaga keberlangsungan hidup dan kinerja perusahaan, perusahaan dituntut untuk mengetahui kondisi yang terjadi di dalam perusahaannya (Paleni, 2015). Kondisi internal yang menjadi salah satu fokus perhatian perusahaan adalah kondisi keuangan perusahaan khususnya dengan melakukan analisis laporan perusahaan. Hal ini karena perusahaan dengan kondisi keuangan yang baik menjadi salah satu kekuatan perusahaan untuk bertahan dan mencapai tujuan atau kinerja terbaik perusahaan.

Dalam rangka memenuhi kebutuhan air bersih masyarakat Perusahaan Daerah Air Minum (PDAM) didirikan di berbagai daerah di Indonesia (Mintarti, 2012). Menurut Widyanto (2012) PDAM memiliki dua fungsi yang harus dilaksanakan, yaitu berorientasi sosial dan berorientasi laba. Berorientasi sosial berarti PDAM berfungsi harus melayani masyarakat yang baik dalam menyediakan air bersih, sedangkan berorientasi laba berarti PDAM berfungsi untuk membiayai operasi perusahaannya dengan memperoleh laba dan untuk menambah penerimaan daerah.

Untuk mendorong suatu perusahaan mencapai tujuan atau menjalankan fungsinya perlu diadakan evaluasi terhadap kinerja yang telah dilakukan. Evaluasi ini berguna untuk pengambilan keputusan yang tepat untuk pencapaian tujuan. Kinerja perusahaan menjadi tolak ukur perkembangan suatu perusahaan, salah satu yang 
menjadi fokus adalah kinerja keuangannya. Kinerja keuangan dapat dinilai dari baik tidaknya laporan keuangan. Badan Pengawasan Keuangan dan Pembangunan (BPKP) merujuk Keputusan Menteri Dalam Negeri Nomor 47 tahun 1999 tentang Pedoman Penilaian Kinerja Perusahaan Daerah Air Minum. Peraturan tersebut terdiri dari tiga indikator, yaitu keuangan, operasional dan administrasi.

Beberapa penelitian sebelumnya juga menganalisis kinerja keuangan pada perusahaan (Dewi, 2017; Hilman et al., 2014; Zannati et al., 2016) dan beberapa penelitian khusus menilai kinerja pada PDAM di beberapa kota berbeda (Hasyboni, 2013; Hatim, 2017; Mintarti, 2012; Paleni, 2015). Pada penelitian ini bertujuan untuk mengukur dan menganalisis kinerja keuangan PDAM di Kota Makassar. Analisis ini didasarkan pada peraturan normatif surat Keputusan Menteri Dalam Negeri (Kepmendagri) Nomor 47 Tahun 1999 tanggal 31 Mei 1999. Penelitian ini diharapkan memberikan manfaat secara teoritis dalam hal memperdalam pengetahuan di bidang akuntansi keuangan khususnya dalam menganalisa kinerja keuangan perusahaan. Selain itu penelitian ini juga diharapkan memberikan manfaat praktis kepada PDAM salah satu pertimbangan untuk menilai dan mengevaluasi kinerja keuangan untuk meningkatkan pengoptimalan pemanfaatan sumber daya.

\section{Telaah Pustaka}

\section{Kinerja Keuangan}

Kinerja keuangan merupakan informasi mengenai kondisi keuangan dan interpretasi dari efektivitas dan efisiensi dari pengelolaan operasional keuangan untuk memperoleh laba maksimal (Efriyanti et al., 2012). Fahmi (2013) juga berpendapat kinerja keuangan dilakukan untuk menilai apakah perusahaan telah menjalankan proses keuangannya sesuai pedoman. Kinerja keuangan suatu perusahaan menunjukkan seberapa sehat perusahaan tersebut. Apabila kinerja keuangan perusahaan tersebut baik, maka perusahaan tersebut dapat dikatakan perusahaan yang sehat. Dapat diartikan bahwa kinerja keuangan merupakan informasi yang menggambarkan proses keuangan yang dijalankan sebuah perusahaan dalam periode tertentu.

\section{Laporan Keuangan}

Laporan keuangan merupakan hasil akhir dari proses pencatatan dan perhitungan yang berisi ringkasan transaksi-transaksi keuangan selama periode tertentu. Menurut Hery (2015) laporan keuangan merupakan hasil akhir dari proses akuntansi yang berfungsi menjadi media pengkomunikasian data keuangan maupun aktivitas perusahaan kepada pihak-pihak yang berkepentingan. Serupa dengan itu, Pura (2013) juga menyatakan laporan keuangan adalah alat pengkomunikasian dan pertanggungjawaban dari manajemen perusahan ke pemiliknya atau pihak lain yang berhubungan dengan perusahaan yang berguna untuk pengambilan keputusan mereka. 
Standar Standar Akuntansi Keuangan (SAK) menyatakan tujuan laporan keuangan adalah untuk menyediakan informasi tentang kinerja, posisi keuangan, dan perubahannya dalam perusahaan untuk pengambilan keputusan pihak-pihak yang berkepentingan. (Kasmir, 2014) juga menyatakan tujuan dari laporan keuangan yaitu gambaran mengenai jenis dan jumlah aktiva, kewajiban, pendapatan dan biaya atas kepemilikan perusahaan. Laporan keuangan juga bertujuan memberikan informasi tentang perubahan-perubahan yang terjadi terhadap aktiva dan pasiva, kinerja manajemen perusahaan, catatan-catatan atas laporan keuangan dan informasi keuangan lainnya.

Secara umum laporan keuangan terdiri atas laporan laba rugi, laporan perubahan modal, neraca dan laporan arus kas serta catatan atas laporan keuangan (Kasmir, 2014). Laporan laba rugi adalah laporan yang memuat akun-akun dan jumlah pendapatan serta beban perusahaan untuk menghitung laba atau rugi bersih yang didapatkan selama periode tertentu. Laporan perubahan modal memuat informasi jumlah modal yang dimiliki perusahaan selama periode tertentu. Sedangkan neraca adalah jenis laporan memuat akun-akun aktiva, kewajiban, dan modal dalam satu periode tertentu. Laporan arus kas merupakan laporan yang menunjukkan aliran kas masuk dan kas keluar pada periode tertentu. Jenis laporan yang terakhir adalah catatan atas laporan keuangan yang berisi catatan-catatan atau penjelasan dari keempat jenis laporan sebelumnya.

Jenis-jenis laporan keuangan terhubung satu sama lain. Nilai laba atau rugi pada laporan laba rugi akan digunakan untuk menghitung laporan perubahan modal. Nilai modal akhir pada laporan perubahan modal akan menjadi nominal pada neraca pada akun modal. Transaksi-transaksi yang dilakukan selama periode pelaporan akan diidentifikasi transaksi mana saja yang berkaitan dengan kas sebagai dasar pembuatan laporan arus kas. Selanjutnya pada catatan atas laporan keuangan akan dijelaskan cara perhitungan dan penjelasan lain yang diperlukan.

\section{Pedoman Penilaian Kinerja PDAM}

Berdasarkan Kepmendagri No. 47 Tahun 1999 yang berisi dasar penilaian kinerja PDAM, indikator penilaian kinerja PDAM terdiri dari tiga, yaitu operasional administrasi dan keuangan. Pengukuran kinerja ini bertujuan untuk mengetahui keberhasilan perusahaan dalam menjalankan operasinya. Berdasarkan penilaian yang dihitung nantinya akan ditentukan status kinerjanya sesuai dengan kriteria pada tabel 1 untuk indikator operasional dan administrasi sedangkan untuk indikator keuangan sesuai tabel 2. Pengukuran kinerja PDAM pada indikator operasional ditinjau dari 10 indikator, yaitu: 1) cakupan pelayanan; 2) kualitas air berdasarkan peraturan Menteri Kesehatan; 3) kontinuitas pengaliran air bersih; 4) produktivitas jumlah kapasitas produksi dan kapasitas terpasang; 5) kehilangan air bersih; 6) peneraan meter air; 7) kecepatan penyambungan baru; 8) kemampuan penanganan pengaduan; 9) kemudahan pelayanan; 10) rasio jumlah karyawan. 
Penilaian indikator operasional:

$$
\frac{\text { Jumlah nilai yang diperoleh }}{47} \times 40
$$

Keterangan:

47 : nilai maksimum indikator aspek operasional

40 : bobot kinerja aspek operasional

\section{Tabel 1. Kriteria Penetapan Status Kinerja}

\begin{tabular}{clll}
\hline No & & Kriteria & Nilai \\
\hline 1. & Baik Sekali & $>75$ & \\
2. & Baik & $>60 \mathrm{~s} / \mathrm{d} 75$ & \\
3. & Cukup & $>45 \mathrm{~s} / \mathrm{d} 60$ & \\
4. & Kurang & $>30 \mathrm{~s} / \mathrm{d} 45$ & \\
5. & Tidak Baik & $<=30$ & \\
\hline
\end{tabular}

Sumber: Kepmendagri No.47 tahun 1999, 2019

Indikator penilaian yang kedua adalah administrasi. Indikator penilaian administrasi juga meliputi 10 indikator, yaitu: 1) rencana jangka panjang (corporate plan); 2) rencana organisasi dan uraian tugas; 3) prosedur operasi standar; 4) gambar nyata laksana (as built drawing); 5) pedoman penilaian kerja karyawan; 6) tertib laporan internal; 7) tertib laporan eksternal; 8) Rencana Kerja dan Anggaran Perusahaan (RKAP); 9) opini auditor independen; 10) tindak lanjut hasil pemeriksaan tahun terakhir.

Penilaian indikator administrasi:

$$
\frac{\text { Jumlah nilai yang diperoleh }}{36} \times 16
$$

Keterangan:

16 : nilai maksimum indikator aspek administrasi

36 : bobot kinerja aspek administrasi

Pengukuran kinerja PDAM yang ketiga adalah kinerja keuangan dengan 10 indikator yaitu: 1) rasio laba terhadap aktiva produktif; 2) rasio laba terhadap penjualan; 3) rasio aktiva lancar terhadap hutang lancar; 4) rasio hutang jangka panjang terhadap ekuitas; 5) rasio total aktiva terhadap hutang; 6) rasio biaya operasi terhadap pendapatan operasi; 7) rasio laba operasi sebelum biaya penyusutan terhadap angsuran pokok dan bunga jatuh tempo; 8) rasio aktiva produktif terhadap penjualan air; 9) rasio jangka waktu penagihan piutang; 10) rasio efektivitas penagihan.

Penilaian indikator keuangan:

$$
\frac{\text { Jumlah nilai yang diperoleh }}{60} \times 45
$$

Keterangan:

60 : nilai maksimum indikator aspek keuangan

45 : bobot kinerja aspek keuangan 
Khusus untuk kinerja keuangan kriteria penetapan status pencapaian kinerja didasarkan pada tabel 2 berikut:

\section{Tabel 2. Kriteria Penetapan Status Kinerja Keuangan}

\begin{tabular}{cll}
\hline NO & \multicolumn{1}{c}{ Kriteria Aspek Keuangan } & \multicolumn{1}{c}{ Nilai } \\
\hline 1. & Baik Sekali & $>33,75$ \\
2. & Baik & $>27 \mathrm{~s} / \mathrm{d} \mathrm{33,75}$ \\
3. & Cukup & $>20,25 \mathrm{~s} / \mathrm{d} \mathrm{27}$ \\
4. & Kurang & $>13,5 \mathrm{~s} / \mathrm{d} \mathrm{20,25}$ \\
5. & Tidak Baik & $<=13,5$ \\
\hline
\end{tabular}

Sumber: Kepmendagri No.47 tahun 1999, 2019

\section{Kerangka Pikir}

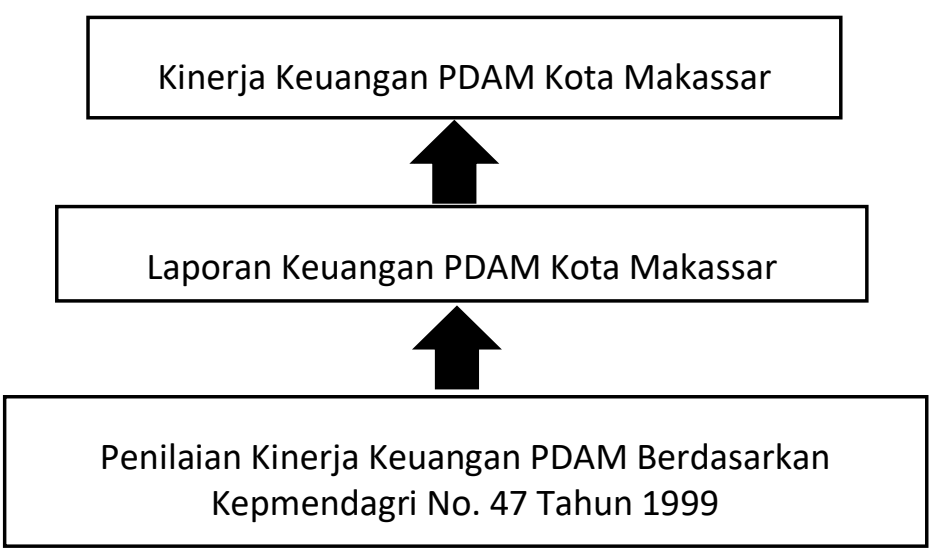

Gambar 1. Kerangka Pikir Penelitian

\section{Metoda}

Penelitian merupakan penelitian kuantitatif dengan data sekunder. Data sekunder, yaitu data yang diperoleh dari laporan keuangan serta dokumen lain yang berhubungan dengan keuangan Perusahaan Daerah Air Minum (PDAM) Kota Makassar pada Periode 2015-2017. Data diperoleh secara langsung dari PDAM kota Makassar. Penelitian ini menggunakan teknik analisis deskriptif dengan menggambarkan kinerja PDAM Kota Makassar dari indikator keuangan berdasarkan Kepmendagri No. 47 Tahun 1999 yang berisi dasar penilaian kinerja PDAM. Data yang diperoleh akan dihitung dan ditentukan status kinerjanya dengan menggunakan rasio-rasio indikator keuangan. 
Tabel 3. Indikator Penelitian

\begin{tabular}{|c|c|c|}
\hline Indikator & Rumus & Pembobotan \\
\hline \multirow{10}{*}{$\begin{array}{l}\text { Rasio Laba terhadap } \\
\text { Aktiva Produktif }\end{array}$} & & 5: $>10 \%$ \\
\hline & (Laba Bersih Sebelum & $4:>7 \%-10 \%$ \\
\hline & Pajak)/(Aktiva Produktif) & $3:>3 \%-7 \%$ \\
\hline & $\mathrm{X} 100$ & $2: 0 \%-3 \%$ \\
\hline & & $1:<0 \%$ \\
\hline & Penambahan = Rasio Laba & $5:>12 \%$ \\
\hline & terhadap Aktiva Produktif & $4:>9 \%-12 \%$ \\
\hline & tahun ini-Rasio Laba & $3:>6 \%-9 \%$ \\
\hline & terhadap Aktiva Produktif & $2:>3 \%-6 \%$ \\
\hline & tahun lalu & $1:<0 \%-3 \%$ \\
\hline \multirow{10}{*}{$\begin{array}{l}\text { Rasio Laba terhadap } \\
\text { Penjualan }\end{array}$} & \multirow{5}{*}{$\begin{array}{l}\text { (Laba Bersih Sebelum } \\
\text { Pajak)/Penjualan x 100\% }\end{array}$} & 5: $>20 \%$ \\
\hline & & 4: >14\%-20\% \\
\hline & & 3: $>6 \%-14 \%$ \\
\hline & & $2: 0 \%-6 \%$ \\
\hline & & $1:<0 \%$ \\
\hline & \multirow{5}{*}{$\begin{array}{l}\text { Penambahan = Rasio Laba } \\
\text { terhadap Penjualan tahun } \\
\text { ini-Rasio Laba terhadap } \\
\text { Penjualan tahun lalu }\end{array}$} & $5:>12 \%$ \\
\hline & & $4:>9 \%-12 \%$ \\
\hline & & $3:>6 \%-9 \%$ \\
\hline & & $2:>3 \%-6 \%$ \\
\hline & & $1:<0 \%-3 \%$ \\
\hline \multirow{5}{*}{$\begin{array}{l}\text { Rasio Aktiva Lancar } \\
\text { terhadap Utang } \\
\text { Lancar/Rasio Lancar } \\
\text { (Current Ratio) }\end{array}$} & \multirow{5}{*}{$\begin{array}{l}\text { (Aktiva Lancar)/(Utang } \\
\text { Lancar) }\end{array}$} & $5:>1,75-2,00$ \\
\hline & & $4:>1,50-1,75 ;$ atau $>2,00-2,30$ \\
\hline & & $3:>1,25-1,50 ;$ atau $>2,30-2,70$ \\
\hline & & $2:>1,00-1,25 ;$ atau $>2,70-3,00$ \\
\hline & & $1:<1,00 ;$ atau $>3,00$ \\
\hline \multirow{5}{*}{$\begin{array}{l}\text { Rasio Utang Jangka } \\
\text { Panjang terhadap } \\
\text { Ekuitas/Debt to Equity } \\
\text { Ratio }\end{array}$} & \multirow{5}{*}{$\begin{array}{l}\text { (Utang Jangka } \\
\text { Panjang)/Ekuitas }\end{array}$} & $5:<0,50$ \\
\hline & & $4:>0,50-0,70$ \\
\hline & & $3:>0,70-0,80$ \\
\hline & & $2:>0,80-1,00$ \\
\hline & & $1:>1,00$ \\
\hline \multirow{5}{*}{$\begin{array}{l}\text { Rasio Total Aktiva } \\
\text { terhadap Total } \\
\text { Utang/Rasio } \\
\text { Solvabilitas }\end{array}$} & \multirow{5}{*}{$\begin{array}{l}\text { (Total Aktiva )/(Total } \\
\text { Utang) }\end{array}$} & $5:>2,00$ \\
\hline & & $4:>1,70-2,00$ \\
\hline & & $3:>1,30-1,70$ \\
\hline & & $2:>1,00-1,30$ \\
\hline & & $1:<1,00$ \\
\hline \multirow{5}{*}{$\begin{array}{l}\text { Rasio Biaya Operasi } \\
\text { terhadap Pendapatan } \\
\text { Operasi/Rasio Operasi } \\
\text { (Operating Ratio) }\end{array}$} & \multirow{5}{*}{$\begin{array}{l}\text { (Biaya } \\
\text { Operasi)/(Pendapatan } \\
\text { Operasi) }\end{array}$} & $5:<0,50$ \\
\hline & & $4:>0,50-0,65$ \\
\hline & & $3:>0,65-0,85$ \\
\hline & & $2:>0,85-1,00$ \\
\hline & & $1:>1,00$ \\
\hline \multirow{5}{*}{$\begin{array}{l}\text { Rasio Laba Operasi } \\
\text { sebelum Biaya } \\
\text { Penyusutan terhadap } \\
\text { Angsuran Pokok dan } \\
\text { Bunga Jatuh Tempo }\end{array}$} & (Laba Operasi Sebelum & $5:>2,00$ \\
\hline & Biaya & $4:>1,70-2,00$ \\
\hline & Penyusutan)/(Angsuran & $3:>1,30-1,70$ \\
\hline & Pokok + Bunga Jatuh & $2:>1,00-1,30$ \\
\hline & Tempo) & $1:<1,00$ \\
\hline \multirow{5}{*}{$\begin{array}{l}\text { Rasio Aktiva Produktif } \\
\text { terhadap Penjualan Air }\end{array}$} & \multirow{5}{*}{$\begin{array}{l}\text { (Aktiva } \\
\text { Produktif)/(Penjualan Air) }\end{array}$} & $5:<2,00$ \\
\hline & & $4:>2,00-4,00$ \\
\hline & & $3:>4,00-6,00$ \\
\hline & & $2:>6,00-8,00$ \\
\hline & & $1:>8,00$ \\
\hline \multirow{4}{*}{$\begin{array}{l}\text { Jangka Waktu } \\
\text { Penagihan Piutang }\end{array}$} & \multirow{4}{*}{$\begin{array}{l}\text { (Piutang Usaha)/(Jumlah } \\
\text { Penjualan Per Hari) }\end{array}$} & $5:<60$ \\
\hline & & $4:>60-90$ \\
\hline & & $3:>90-150$ \\
\hline & & $2:>150-180$ \\
\hline
\end{tabular}




\begin{tabular}{lll}
\hline & & $1:>180$ \\
\hline & & $5:>90 \%$ \\
Efektivitas Penagihan & $4:>85 \%-90 \%$ \\
& (Rekening Tertagih)/ & $3:>80 \%-85 \%$ \\
& & $2: 75 \%-80 \%$ \\
& $1:<75 \%$
\end{tabular}

Sumber: Kepmendagri No.47 tahun 1999, 2019

Analisis data dilakukan dengan menghitung 10 indikator dengan rumus sesuai tabel 3. Rumus tersebut didasarkan pada Kepmendagri No. 47 Tahun 1999 tentang penilaian kinerja PDAM. Setelah itu, berdasarkan hasil perhitungan akan dilakukan pembobotan untuk menilai kinerja keuangan PDAM. Pembobotan akan dijumlah kemudian digunakan untuk menghitung kinerja keuangan PDAM untuk selanjutnya diberikan kategori status kinerja keuangan sesuai tabel 2 .

\section{Hasil dan Pembahasan}

\section{Profil PDAM Kota Makassar}

Berdasarkan informasi melalui website, Perusahaan Daerah Air Minum (PDAM) Kota Makassar terletak di Jalan Dr. Ratulangi no. 3 Kota Makassar. PDAM Kota Makassar memiliki empat lokasi instalasi pengolahan air. Lokasi pengolahan air yang pertama terletak di lokasi yang sama dengan kantornya. Lokasi ini merupakan lokasi pertama yang dahulu dibangun oleh Belanda dengan kapasitas $50 \mathrm{l} / \mathrm{d}$. Lokasi kedua terletak di Panaikang Kota Makassar dengan kapasitas 1.000 l/d. Instalasi Pengolahan Air II Panaikang melayani 20 zona aliran di Kota Makassar. Lokasi ketiga yaitu Instalasi Pengolahan Air III Antang yang terletak di Jalan Antang Raya. Instalasi pengolahan air di Atang ini khusus melayani zona 34 dengan kapasitas produksi 90 l/d. Lokasi terakhir yaitu Instalasi Pengolahan Air IV Maccini Sombala yang memiliki kapasitas produksi 200 l/d serta melayani dua zona yang ada di Kota Makassar.

PDAM Kota Makassar berkomitmen dalam hal kualitas, pelayanan dan professional. Dalam hal kualitas PDAM Kota Makassar memastikan air yang dialirkan kepada masyarakat merupakan kualitas air terbaik. Selain itu mereka juga berkomitmen selalu melayani bahkan meningkatkan pelayanan demi kepuasan pelanggan serta kesejahteraan karyawan. PDAM Kota Makassar juga berkomitmen untuk menjadikan perusahaannya sebagai perusahaan yang profesional, berkompetensi dan berdaya saing tinggi. 


\section{Hasil dan Pembahasan}

Berdasarkan laporan keuangan PDAM kota Makassar dilakukan perhitungan atas 10 kriteria penilaian kinerja keuangan sesuai aturan Kepmendagri No. 47 Tahun 1999. Perhitungan dan pembobotan pada setiap indikator sesuai dengan tabel 4 .

Tabel 4. Perhitungan dan Pembobotan Indikator Rasio Laba terhadap Aktiva Produktif

\begin{tabular}{|c|c|c|c|c|}
\hline Indikator & Tahun & Rumus & & bobotan \\
\hline \multirow{5}{*}{$\begin{array}{l}\text { Rasio } \\
\text { terhadap } \\
\text { Produktif }\end{array}$} & 2015 & $\begin{array}{l}(64.422 .725 .123) /(303.901 .197 .426) \\
100=21,20 \%\end{array}$ & $\mathrm{x}$ & 5 \\
\hline & 2016 & $\begin{array}{l}(85.335 .229 .437) /(358.740 .657 .563) \\
100=23,79 \%\end{array}$ & $\mathrm{x}$ & 5 \\
\hline & 2017 & $\begin{array}{l}(100.560 .598 .162) /(405.122 .457 .062) \\
100=24,82 \%\end{array}$ & $\mathrm{x}$ & 5 \\
\hline & 2016 & $\begin{array}{l}\text { Penambahan: } \\
23,79 \%-21,20 \%=2,59 \%\end{array}$ & & 1 \\
\hline & 2017 & $\begin{array}{l}\text { Penambahan: } \\
24,82 \%-23,79 \%=1,03 \%\end{array}$ & & 1 \\
\hline
\end{tabular}

Sumber: Data yang telah diolah, 2019

Dari tabel 4 diketahui bahwa PDAM Kota Makassar memiliki kinerja yang baik, berdasarkan kemampuan dalam menghasilkan laba dari jumlah aset produktif yang dikelola. Pada tahun 2015 Perusahaan Daerah Air Minum (PDAM) Kota Makassar dapat menghasilkan laba Rp 64.422.725.122,- dengan rasio 21,20\%. Kemudian pada tahun 2016 Perusahaan Daerah Air Minum (PDAM) Kota Makassar berhasil meningkatkan laba perusahaannya sebesar Rp 85.335.229.437,- sehingga rasio meningkat menjadi 23,79\% dan kemudian pada tahun 2017 Perusahaan Daerah Air Minum (PDAM) Kota Makassar kembali berhasil meningkatkan laba perusahaannya sebesar Rp 100.560.598.162,- sehingga rasio menjadi 24,82\%. Dengan demikian dari tahun 2015-2017 Perusahaan Daerah Air Minum (PDAM) Kota Makassar menghasilkan nilai kinerja 5 (lima). Hal tersebut berarti Perusahaan Daerah Air Minum (PDAM) Kota Makassar mampu memanfaatkan aktiva produktif yang dimiliki untuk menghasilkan laba bagi perusahaan. Peningkatan rasio laba terhadap aktiva produktif di tahun 2015 ke tahun 2016 sebesar 2,59\% dan selanjutnya peningkatan rasio laba terhadap aktiva produktif di tahun 2016 ke tahun 2017 mengalami penurunan menjadi $1,03 \%$. Hal ini dapat dilihat jika perubahan rasio di tiap tahunnya tidak dapat dipengaruhi oleh peningkatan laba terhadap aktiva produktifnya. 
Tabel 5. Perhitungan dan Pembobotan Indikator Rasio Laba terhadap Penjualan

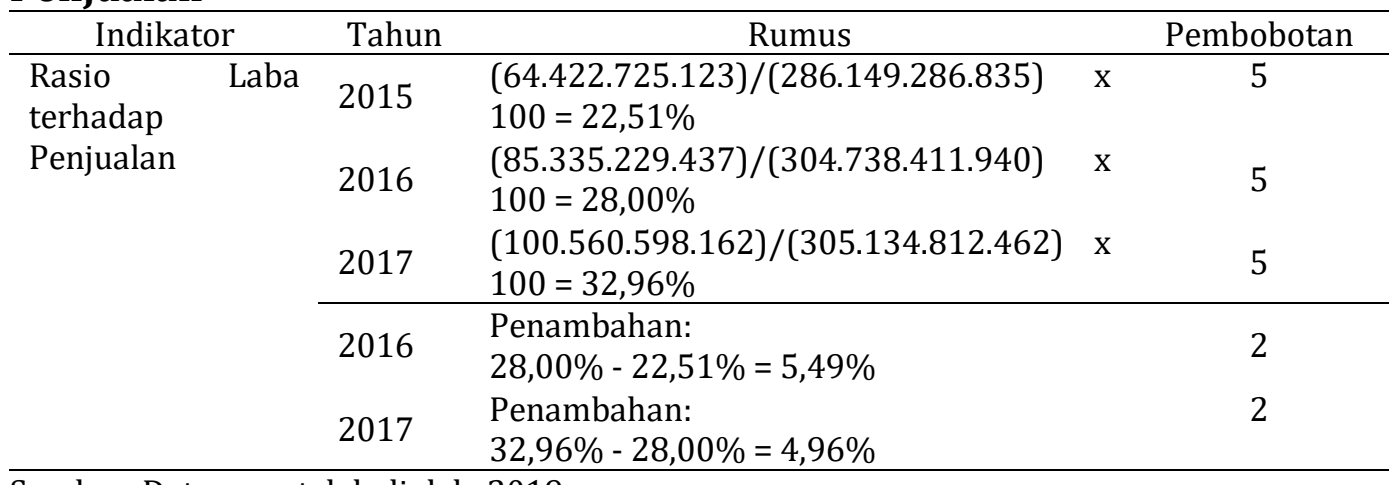

Sumber: Data yang telah diolah, 2019

Rasio laba terhadap penjualan tahun 2015 sebesar 22,51\%, kemudian mengalami kenaikan rasio pada tahun 2016 yaitu sebesar 28,00\% dan pada tahun 2017 mengalami kenaikan kembali dengan rasio sebesar 32,96\%, dengan rata-rata rasio 27,82\% dalam tiga tahun terakhir. Dengan demikian dari tahun 2015-2017 Perusahaan Daerah Air Minum (PDAM) Kota Makassar menghasilkan nilai kinerja 5 (lima). Kenaikan pada rasio ini disebabkan oleh naiknya tarif air yang terjadi dari akhir tahun 2015 sampai tahun 2017, yang memiliki dampak positif pada harga pokok penjualan air sehingga turut berpengaruh terhadap laba yang dihasilkan oleh perusahaan. Peningkatan rasio laba terhadap penjualan pada tahun 2016 sebesar 5,49\% dan terjadi sedikit penurunan di tahun 2017 menjadi 4,96\%. Hal ini disebabkan Perusahaan Daerah Air Minum (PDAM) Kota Makassar masih kurang mampu mengoptimalkan peningkatan rasio laba terhadap penjualan di tiap tahunnya.

Tabel 6. Perhitungan dan Pembobotan Indikator Rasio Aktiva Lancar terhadap Utang Lancar/Rasio Lancar (Current Ratio)

\begin{tabular}{|c|c|c|c|c|}
\hline Indikator & Tahun & Rumus & & Pembobotan \\
\hline $\begin{array}{lr}\text { Rasio } & \text { Aktiva } \\
\text { Lancar } & \text { terhadap }\end{array}$ & 2015 & $\begin{array}{l}(122.911 .444 .682) /(241.949 .624 .256) \\
0,51\end{array}$ & $=$ & 1 \\
\hline $\begin{array}{l}\text { Utang } \\
\text { Lancar/Rasio }\end{array}$ & 2016 & $\begin{array}{l}(178.240 .011 .713) /(42.540 .000 .473) \\
4,19\end{array}$ & $=$ & 5 \\
\hline $\begin{array}{l}\text { Lancar (Current } \\
\text { Ratio) }\end{array}$ & 2017 & $\begin{array}{l}(202.319 .677 .859) /(65.169 .950 .694) \\
3,10\end{array}$ & $=$ & 5 \\
\hline
\end{tabular}

Sumber: Data yang telah diolah, 2019

Rasio aktiva lancar terhadap utang lancar pada tahun 2015 dan tahun 2016 mengalami peningkatan, dilihat dari tahun 2015 rasio lancar yang didapatkan oleh perusahaan sebesar 0,51 yang menghasilkan nilai kinerja 1 (satu) sesuai dengan tabel 6. Hal ini disebabkan karena total hutang lancar Rp 241.949.624.256,- di tahun 2015 lebih besar dibandingkan dengan total aktiva lancar yaitu Rp 122.911.444.682,-. Kemudian di tahun 2016 rasio yang didapatkan oleh perusahaan sebesar 4,19 yang menghasilkan nilai kinerja 5 (lima). Namun pada tahun 2017 mengalami penurunan menjadi 3,10, tetapi rasio lancar tahun 2017 masih menunjukan nilai kinerja 5 (lima). Terjadinya penurunan rasio lancar tahun 2017 disebabkan karena meningkatnya hutang usaha ditahun tersebut menjadi Rp 40.363.257.869,- sehingga total hutang 
lancar pun meningkat menjadi Rp 65.169.950.694,- dengan rasio lancar menjadi 3,10 dengan perolehan nilai kinerja 5 (lima). Jadi dapat diartikan bahwa dalam 3 tahun terakhir Perusahaan Daerah Air Minum (PDAM) Kota Makassar telah mampu memanfaatkan aktiva lancarnya secara maksimal untuk memenuhi kewajibankewajiban jangka pendeknya.

Tabel 7. Perhitungan dan Pembobotan Indikator Rasio Utang Jangka Panjang terhadap Ekuitas/Debt to Eqiuty Ratio

\begin{tabular}{|c|c|c|c|}
\hline Indikator & Tahun & Rumus & Pembobotan \\
\hline $\begin{array}{lr}\text { Rasio } & \text { Utang } \\
\text { Jangka } & \text { Panjang }\end{array}$ & 2015 & $\begin{array}{l}(9.710 .550 .383) /(65.418 .521 .285) \\
=0,15\end{array}$ & 5 \\
\hline $\begin{array}{l}\text { terhadap } \\
\text { Ekuitas/Debt to }\end{array}$ & 2016 & $\begin{array}{l}(0) /(335.285 .128 .808) \\
=0\end{array}$ & 5 \\
\hline Eqiuty Ratio & 2017 & $\begin{array}{l}(0) /(366.074 .564 .166) \\
=0\end{array}$ & 5 \\
\hline
\end{tabular}

Sumber: Data yang telah diolah, 2019

Tabel 4 juga menunjukkan rasio utang jangka panjang terhadap ekuitas, dalam kurun waktu 3 (tiga) tahun terakhir yaitu dari tahun 2015 sampai dengan 2017 mengalami penurunan rasio secara terus menerus, yaitu 0,15 di tahun 2015, 0 di tahun 2016 dan di tahun 2017. Namun dengan adanya penurun tersebut tidak berarti negatif bagi Perusahaan Daerah Air Minum (PDAM), karena pada rasio ini Perusahaan Daerah Air Minum (PDAM) Kota Makassar mendapat nilai kinerja 5 (lima) atau dapat dikategorikan baik. Hal tersebut berarti jumlah ekuitas perusahaan dari tahun 20152017 dapat menutup seluruh utang jangka panjang perusahaan.

Tabel 8. Perhitungan dan Pembobotan Indikator Rasio Total Aktiva terhadap Total Utang/Rasio Solvabilitas

\begin{tabular}{|c|c|c|c|}
\hline & Tahun & Rumus & Pembobotan \\
\hline \multirow{3}{*}{$\begin{array}{l}\text { Rasio Total Aktiva } \\
\text { terhadap Total } \\
\text { Utang/Rasio } \\
\text { Solvabilitas }\end{array}$} & 2015 & $\begin{array}{l}(317.078 .695 .924) /(251.660 .174 .639) \\
1,26\end{array}$ & 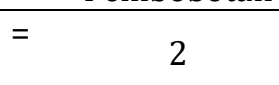 \\
\hline & 2016 & $\begin{array}{l}(377.825 .129 .281) /(42.540 .000 .473) \\
8,88\end{array}$ & 5 \\
\hline & 2017 & $\begin{array}{l}(431.244 .514 .860) /(65.169 .950 .694) \\
6,62\end{array}$ & $=$ \\
\hline
\end{tabular}

Sumber: Data yang telah diolah, 2019

Pada rasio total aktiva terhadap total utang dari tahun 2015 hingga tahun 2017, terlihat rasio yang telah dicapai dari tahun 2015 sebesar 1,26 yang menghasilkan nilai kinerja 2 (dua) dalam tahun 2015 ini Perusahaan Daerah Air Minum (PDAM) Kota Makassar masih kurang kurang baik. Namun pada tahun 2016 rasio mengalami peningkatan sebesar 8,88 dan menghasilkan nilai kinerja 5 (lima). Pada tahun 2017 terjadi penurunan rasio menjadi 6,62, tetapi tidak perlu dikhawatirkan karena rasio tahun 2017 masih menunjukkan nilai kinerja 5 (lima) dan masih tergolong baik. Sehingga Perusahaan Daerah Air Minum (PDAM) Kota Makassar dianggap mampu mengoptimalkan penggunaan aset-aset perusahaan untuk memperoleh laba yang maksimal, yang dapat menurunkan utang. 
Tabel 9. Perhitungan dan Pembobotan Indikator Rasio Biaya Operasi terhadap Pendapatan Operasi/Rasio Operasi (Operating Ratio)

\begin{tabular}{|c|c|c|c|}
\hline Indikator & Tahun & Rumus & Pembobotan \\
\hline $\begin{array}{l}\text { Rasio } \quad \text { Biaya } \\
\text { Operasi terhadap }\end{array}$ & 2015 & $\begin{array}{l}(228.360 .302 .522) /(286.149 .286 .835) \\
0,80\end{array}$ & 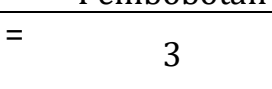 \\
\hline $\begin{array}{l}\text { Pendapatan } \\
\text { Operasi/Rasio }\end{array}$ & 2016 & $\begin{array}{l}(236.452 .763 .790) /(304.738 .411 .940) \\
0,78\end{array}$ & 3 \\
\hline $\begin{array}{l}\text { Operasi } \\
\text { (Operating Ratio) }\end{array}$ & 2017 & $\begin{array}{l}(254.909 .329 .041) /(305.134 .812 .462) \\
0,84\end{array}$ & 3 \\
\hline
\end{tabular}

Sumber: Data yang telah diolah, 2019

Rasio biaya operasi terhadap pendapatan operasi yang ditunjukkan tabel 9, tahun 2015 sampai 2016 telah rasio sedikit mengalami penurunan yaitu 0,78. Namun mengalami peningkatan kembali pada tahun 2017 menjadi 0,84 dengan rata-rata rasio 0,81. Sehingga dari 3 (tiga) tahun terakhir nilai kinerja yang dihasilkan yaitu 3 (tiga) yang berarti pendapatan operasi perusahaan belum cukup maksimal terhadap biaya operasi perusahaan.

Tabel 10. Perhitungan dan Pembobotan Indikator Rasio Laba Operasi sebelum Biaya Penyusutan terhadap Angsuran Pokok dan Bunga Jatuh Tempo

\begin{tabular}{|c|c|c|c|}
\hline Indikator & Tahun & Rumus & Pembobotan \\
\hline $\begin{array}{lr}\text { Rasio } & \text { Laba } \\
\text { Operasi } & \text { sebelum }\end{array}$ & 2015 & $\begin{array}{l}(92.647 .696 .158) /(9.710 .550 .383) \\
=9,54\end{array}$ & 5 \\
\hline $\begin{array}{l}\text { Biaya Penyusutan } \\
\text { terhadap }\end{array}$ & 2016 & $\begin{array}{l}(93.503 .290 .437) /(0) \\
=\infty\end{array}$ & 5 \\
\hline $\begin{array}{l}\text { Angsuran Pokok } \\
\text { dan Bunga Jatuh } \\
\text { Tempo }\end{array}$ & 2017 & $\begin{array}{l}(75.859 .910 .568) /(0) \\
=\infty\end{array}$ & 5 \\
\hline
\end{tabular}

Sumber: Data yang telah diolah, 2019

Pada tabel 10 rasio laba operasi sebelum biaya penyusutan terhadap angsuran pokok dan bunga jatuh tempo 2015 mendapatkan nilai 9,54, namun di tahun 2016 menjadi $\infty$ (tak terhingga) sampai dengan tahun 2017, diperkirakan pihak perusahaan tidak memiliki hutang jatuh tempo karena telah dihapuskan, sehingga dapat dikatakan hutang jangka panjang jatuh tempo Perusahaan Daerah Air Minum (PDAM) Kota Makassar telah lunas. Dan hal tersebut berdampak baik pada rasio perolehan bagi Perusahaan Daerah Air Minum (PDAM) Kota Makassar.

Tabel 11. Perhitungan dan Pembobotan Indikator Rasio Aktiva Produktif terhadap Penjualan Air

\begin{tabular}{|c|c|c|c|}
\hline Indikator & Tahun & Rumus & Pembobotan \\
\hline \multirow{3}{*}{$\begin{array}{l}\text { Rasio Aktiva } \\
\text { Produktif } \\
\text { terhadap } \\
\text { Penjualan Air }\end{array}$} & 2015 & $\begin{array}{l}(303.901 .197 .426) /(272.567 .101 .073) \\
1,11\end{array}$ & 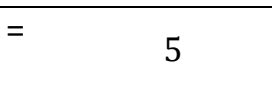 \\
\hline & 2016 & $\begin{array}{l}(358.740 .657 .563) /(286.367 .003 .080) \\
1,25\end{array}$ & 5 \\
\hline & 2017 & $\begin{array}{l}(405.122 .457 .062) /(292.746 .055 .793) \\
1,38\end{array}$ & 5 \\
\hline
\end{tabular}

Sumber: Data yang telah diolah, 2019

Begitu pula dengan rasio aktiva produktif terhadap penjualan air, rasio ditahun 2015 menunjukkan 1,11, selanjutnya di tahun 2016 sampai dengan tahun 2017 rasio 
mengalami peningkatan menjadi 1,25 dan 1,38 dengan rata-rata rasio 1,25 , sehingga menghasilkan nilai kinerja 5 (lima) yang tergolong baik bagi Perusahaan Daerah Air Minum (PDAM) Kota Makassar.

\begin{tabular}{|c|c|c|c|}
\hline Indikator & Tahun & Rumus & Pembobotan \\
\hline \multirow{3}{*}{$\begin{array}{ll}\text { Jangka } & \text { Waktu } \\
\text { Penagihan } & \\
\text { Piutang } & \end{array}$} & 2015 & $\begin{array}{l}(28.118 .875 .279) /(794.859 .130) \\
=35,38\end{array}$ & 5 \\
\hline & 2016 & $\begin{array}{l}(29.081 .073 .309) /(846.495 .588) \\
=34,35\end{array}$ & 5 \\
\hline & 2017 & $\begin{array}{l}(30.772 .647 .414) /(847.596 .701) \\
=36,31\end{array}$ & 5 \\
\hline
\end{tabular}

Sumber: Data yang telah diolah, 2019

Berdasarkan tabel 12 jangka waktu penagihan piutang, terlihat di tahun 2015 yaitu 35,38, pada tahun 2016 terjadi sedikit penurunan jangka waktu piutang tertagih menjadi 34,35. Namun hal tersebut tidak berdampak negatif bagi Perusahaan Daerah Air Minum (PDAM) Kota Makassar, karena nilai kinerja yang dihasilkan masih tergolong baik. dan pada tahun terakhir yaitu tahun 2017 terjadi peningkatan kembali menjadi 36,31. Sehingga Perusahaan Daerah Air Minum (PDAM) Kota Makassar dapat memaksimalkan jangka waktu penagihan piutang sebelum berubah menjadi kas.

Tabel 13. Perhitungan dan Pembobotan Indikator Efektivitas Penagihan

\begin{tabular}{cclcc}
\hline \multicolumn{1}{c}{ Indikator } & Tahun & \multicolumn{1}{c}{ Rumus } & Pembobotan \\
\hline Efektivitas & 2015 & $\begin{array}{l}(234.077 .295 .577) /(272.567 .101 .073) \\
\text { Penagihan }\end{array}$ & $\mathrm{x}$ & 4 \\
& $2016=85,88 \%$ & & 4 \\
& $\begin{array}{l}(251.093 .617 .194) /(286.367 .003 .080) \\
100=87,68 \%\end{array}$ & $\mathrm{x}$ & 4 \\
& 2017 & $\begin{array}{l}(248.327 .266 .931) /(292.746 .055 .793) \\
100=84,83 \%\end{array}$ & $\mathrm{x}$ & 3 \\
\hline
\end{tabular}

Sumber: Data yang telah diolah, 2019

Efektivitas penagihan piutangnya, pada tahun 2015 sebesar 85,88\% dan meningkat di tahun 2016 menjadi 87,68\%, namun di tahun 2017 mengalami sedikit penurunan menjadi $84,83 \%$, oleh karena itu rata-ratanya sebesar $86,13 \%$. Tingkat efektivitas penagihan yang telah dicapai oleh PDAM dalam kurun waktu 3 (tiga) tahun terakhir, dipengaruhi oleh sanksi denda jika terlambat melakukan pembayaran serta pemutusan sambungan aliran air jika pembayaran rekening air menunggak sampai 3 bulan. 


\section{Penentuan Kinerja Aspek Keuangan PDAM Kota Makassar}

Dari perhitungan nilai kinerja PDAM Kota Makassar berdasarkan Kepmendagri No. 47 Tahun 1999, diperoleh hasil seperti yang ditunjukan dalam tabel 14 sebagai berikut:

Tabel 14. Hasil Analisis Penilaian Kinerja Aspek Keuangan PDAM Kota Makassar Periode 2015-2017

\begin{tabular}{clccc}
\hline \multirow{2}{*}{ No } & Keterangan & \multicolumn{3}{c}{ Nilai } \\
\cline { 2 - 5 } 1. & $\begin{array}{l}\text { Rasio Laba terhadap Aktiva Produktif } \\
\text { Nilai Bonus : }\end{array}$ & 2015 & 2016 & 2017 \\
\hline 2. & $\begin{array}{l}\text { Rasio Laba terhadap Penjualan } \\
\text { Nilai Bonus : }\end{array}$ & 5 & 5 \\
\hline 3. & $\begin{array}{l}\text { Rasio Aktiva Lancar terhadap Utang Lancar/ Rasio } \\
\text { Lancar (Current Ratio) }\end{array}$ & 5 & 5 & 5 \\
\hline 4. & $\begin{array}{l}\text { Rasio Utang Jangka Panjang terhadap Ekuitas/ Debt to } \\
\text { Equity Ratio }\end{array}$ & 5 & 5 & 5 \\
\hline 5. & $\begin{array}{l}\text { Rasio Total Aktiva terhadap Total Utang/ Rasio } \\
\text { Solvabilitas }\end{array}$ & 2 & 5 & 5 \\
\hline 6. & $\begin{array}{l}\text { Rasio Biaya Operasi terhadap Pendapatan Operasi / } \\
\text { Operating Ratio }\end{array}$ & 3 & 3 & 3 \\
\hline 7. & $\begin{array}{l}\text { Rasio Laba Operasi sebelum Biaya Penyusutan terhadap } \\
\text { Angsuran dan Bunga Jatuh Tempo }\end{array}$ & 5 & 5 & 5 \\
\hline 8. & Rasio Aktiva Produktif terhadap Penjualan Air & 5 & 5 & 5 \\
\hline 9. & Jangka Waktu Penagihan Piutang & 5 & 5 & 5 \\
\hline 10. & Efektivitas Penagihan & 4 & 4 & 3 \\
\hline
\end{tabular}

Sumber : Ringkasan Nilai dari Seluruh Data Olahan PDAM Kota Makassar

Dari tabel 14 ditunjukan bahwa jumlah nilai yang diperoleh untuk tahun 2015 sebesar 40, tahun 2016 sebanyak 50 dan tahun 2017 sebanyak 49. Selanjutnya dilakukan perhitungan untuk menilai kinerja keuangan keuangan untuk tahun 20152017 dengan rumus kinerja keuangan sebagai berikut :

$$
\text { Penilaian Keuangan }=\frac{\text { Jumlah Nilai yang Diperoleh }}{\text { Maksimum Nilai }} \times \text { Bobot }
$$

Tabel 15. Penilaian Tingkat Keberhasilan PDAM Kota Makassar Periode 2015-2017

\begin{tabular}{|c|c|c|c|c|c|}
\hline Tahun & $\begin{array}{c}\text { Nilai } \\
\text { Maksimal }\end{array}$ & Bobot & $\begin{array}{c}\text { Nilai Kinerja Aspek } \\
\text { Keuangan }\end{array}$ & $\begin{array}{l}\text { Klasifikasi } \\
\text { Kinerja }\end{array}$ & Kategori \\
\hline 2015 & \multirow{3}{*}{60} & \multirow{3}{*}{45} & 30 & 66,67 & Baik \\
\hline 2016 & & & 37,49 & 83,31 & Baik sekali \\
\hline 2017 & & & 36,75 & 81,67 & Baik Sekali \\
\hline & Rata - Rata & & 34,75 & 77,22 & BAIK SEKALI \\
\hline
\end{tabular}

Sumber : Data yang telah diolah, 2019

Pada tabel 15 dapat diketahui bahwa, PDAM Kota Makassar tahun 2015 mendapatkan kategori "Baik" dengan klasifikasi kinerja 66,67. Penilaian kinerja keuangan PDAM Kota Makassar meningkat ke kategori "Baik Sekali” dengan klasifikasi kinerja 83,31 pada tahun 2016. Tahun 2017 klasifikasi kinerja turun menjadi 81,67 namun tetap bisa mempertahankan kategori "Baik Sekali". Indikator rasio biaya operasi terhadap 
pendapatan operasi / operating ratio dan efektivitas penagihan perlu mendapat perhatian khusus karena dari 10 indikator dua indikator ini mendapatkan nilai yang lebih sedikit.

\section{Simpulan}

Berdasarkan Kepmendagri No. 47 Tahun 1999 pasal 3 ayat (1), tentang tingkat keberhasilan PDAM, PDAM Kota Makassar mendapatkan kategori "Baik" dengan klasifikasi kinerja 66,67. Penilaian kinerja keuangan PDAM Kota Makassar meningkat ke kategori "Baik Sekali" dengan klasifikasi kinerja 83,31 pada tahun 2016. Tahun 2017 klasifikasi kinerja turun menjadi 81,67 namun tetap bisa mempertahankan kategori "Baik Sekali". Selain itu, kinerja aspek keuangan terbaik ditunjukan pada tahun 2016 dengan nilai perolehan sebanyak 50 poin dari jumlah poin maksimal sebanyak 60 poin, mendapat nilai kinerja 83,31. Namun tingginya kinerja di tahun 2016 juga dikarenakan kenaikan kinerja dapat dipengaruhi dengan adanya kenaikan tarif air PDAM Kota Makassar.

PDAM Kota Makassar perlu mempertahankan bahkan meningkatkan pencapaiannya sampai dengan tahun 2017. PDAM Kota Makassar perlu meningkatkan pencapaiannya pada indikator rasio biaya operasi terhadap pendapatan operasi/operating ratio dan efektivitas penagihan piutang. Penelitian yang dilakukan masih memiliki keterbatasan yaitu, sebagian dari data keuangan tidak dapat ditelusuri lebih lanjut karena keterbatasan dari perusahaan dan ada sebagian data yang dilakukan dengan wawancara. Selain itu tempat penelitian kali ini hanya dilakukan pada satu tempat. Penelitian mendatang diharapkan menambah indikator pengukuran kinerja seperti aspek operasional dan aspek administrasi. Selain itu juga disarankan menambahkan data primer agar diperoleh informasi yang lebih rinci serta diharapkan agar dilakukan pada lebih dari satu objek penelitian dengan harapan diperoleh variasi permasalahan dengan sudut pandang yang lebih banyak. 


\section{Daftar Pustaka}

Dewi, M. (2017). Penilaian Kinerja Keuangan Perusahaan dengan Menggunakan Metode EVA (Economic Value Added) (Studi Kasus pada PT. Krakatau Steel Tbk Periode 2012-2016). Jurnal Manajemen Dan Keuangan, 6(1), 648-659. https://doi.org/2252-844x

Efriyanti, F., Retno, A., \& Yunus, F. (2012). Analisis Kinerja Keuangan Sebagai Dasar Investor Dalam Menanamkan Modal Pada PT. Bukit Asam, Tbk. Jurnal Akuntansi Dan Keuangan, 3(2), 299-316.

Fahmi, I. (2013). Analisis Laporan Keuangan. Alfabeta.

Hasyboni, C. M. (2013). Evaluasi Kinerja Aspek Keuangan Berdasarkan Kepmendagri No.47 Tahun 1999 Pada PDAM Kota Samarinda Periode 2008-2011. EJournal Administrasi Bisnis, 1(47), 17-29.

Hatim, M. R. Bin. (2017). Penilaian Kinerja Perusahaan Daerah Air Minum Tirta Jeneberang Kabupaten Gowa. Makassar. Universitas Hasanuddin.

Hery. (2015). Analisis Kinerja Keuangan Manajemen. Grasindo.

Hilman, R., Nangoy, S. C., \& Tumbel, A. L. (2014). Kinerja Keuangan Menggunakan Analisis Rasio Likuiditas, Leverage, Aktivitas dan profitabilitas Untuk Pengambilan Keputusan Pada PT PLN Area Manado. Jurnal Emba: Jurnal Riset Ekonomi, Manajemen, Bisnis Dan Akuntansi, 2(1), 283-294. https://doi.org/2303-1174

Kasmir. (2014). Analisis Laporan Keuangan (Edisi Pert). Rajawali Press.

Keputusan Menteri Dalam Negeri Nomor 47 tahun 1999 tentang Pedoman Penilaian Kinerja Perusahaan Daerah Air Minum., (1999).

Mintarti, S. (2012). Analisis Kinerja Keuangan Perusahaan Daerah Air Minum Kota Samarinda. Forum Ekonomi: Jurnal Ekonomi, Manajemen Dan Akuntansi, XV(2), 69-80.

Paleni, H. (2015). Analisis Kinerja keuangan Pada PDAM Tirta Bukit Sulap Kota Lubuklinggau. Jurnal Akuntanika, 2(1), 92-104.

Widyanto, E. A. (2012). Analisis Kinerja Keuangan PDAM Tirta Kencana Samarinda Periode 2006-2010 Berdasarkan Sk Mendagri No 47 Th 1999. Jurnal Eksis, 8(1).

Zannati, R., Fitriana, N., \& Artikel, I. (2016). Analisis Laporan Keuangan Pt. Gatari Sebagai Dasar Pertimbangan Pemberian Kredit Modal Kerja Pada Pt.Bank Dki. Jurnal Riset Manajemen Dan Bisnis, 1(2), 81-92. 